\title{
Enemies of liberty? Nationalism, immigration and the framing of terrorism in the agenda of the Front National
}

Article

Accepted Version

Hutchins, R. D. and Halikiopoulou, D. (2019) Enemies of liberty? Nationalism, immigration and the framing of terrorism in the agenda of the Front National. Nations and Nationalism, 26 (1). pp. 67-84. ISSN 1469-8129 doi:

https://doi.org/10.1111/nana.12555 Available at https://centaur.reading.ac.uk/84660/

It is advisable to refer to the publisher's version if you intend to cite from the work. See Guidance on citing.

To link to this article DOI: http://dx.doi.org/10.1111/nana.12555

Publisher: Wiley-Blackwell

All outputs in CentAUR are protected by Intellectual Property Rights law, including copyright law. Copyright and IPR is retained by the creators or other copyright holders. Terms and conditions for use of this material are defined in the End User Agreement.

www.reading.ac.uk/centaur 
Central Archive at the University of Reading

Reading's research outputs online 


\title{
Enemies of liberty? Nationalism, Immigration and the framing of terrorism in the agenda of the Front National ${ }^{i}$
}

Rachel D. Hutchins, Université de Lorraine (France) and City University of New York Daphne Halikiopoulou, University of Reading

**This article has been accepted for publication in Nations and Nationalism. This is the accepted version**

\begin{abstract}
This article systematises the framing of the terrorism issue in the programmatic agenda of the FN by focusing on nationalism. We argue that the FN's position on terrorism constitutes part of its strategy to justify its anti-immigrant agenda by offering ideological rather than biological rationalisations for national belonging. To test our argument empirically we operationalize four categories of nationalism, including ethno-racial, cultural, political-civic and economic, and code official FN materials published in reaction to seven terrorist attacks on French soil during the period 1986-2015. We find that while older documents draw on all four categories, Marine Le Pen documents draw almost exclusively on the cultural and political-civic categories, confirming our argument. Building on the 'normalization' or 'de-demonization' approach, our nationalism framework presents a distinct theoretical advantage by allowing us to conceptualise the shift in the party's programmatic agenda.
\end{abstract}

\section{Introduction}

Terrorism has become an increasingly salient issue across Europe in recent years. Respondents to the Eurobarometer survey cited it as the most important issue facing the EU in Spring 2017 (European Commission 2017), following a series of terrorist attacks in a range of European countries including France, the UK and Belgium. In public perception, terrorism and immigration are frequently linked (Crabtree and Kluch 2016), with citizens concerned by the potential terrorist threat posed by residents as well as nonresidents. This connection presents far-right parties with both opportunities and constraints: on the one hand, they are increasingly incentivised to address the issue of terrorism, which they can link to the main issue they 'own', i.e. immigration, in order to expand their electoral appeal. On the other hand, the fact that many attacks in the 2000s and 2010s have been perpetrated by native-born residents or citizens (Asari et al. 2008: 2), rather than foreign nationals, constrains the ability of these parties to draw a direct link 
between terrorism and immigration. They can attempt to draw this link by identifying Islamic terrorists as foreign according to their descent rather than their citizenship. However, this is another catch-22 for far-right parties because this approach would constitute a race-based framing grounded in origins, rather than socialization and citizenship. As literature (see e.g. Golder 2003; Halikiopoulou et al. 2013) examining farright policies from a rhetorical normalisation approach has argued, the most electorally successful far-right parties in Western Europe are those that are able to build mainstream support by avoiding overtly racist language. Western European far-right parties thus face a dilemma: how to reconcile exclusion on grounds of descent with the need to frame this rhetoric in less racial terms.

Focusing on the French Front National (FN), this article examines the ways in which farright parties address this dilemma. The French context offers a distinct research advantage given the FN's longevity and the recurrence of terrorist attacks on French soil since the establishment of the party. The FN has been increasingly incentivised to include the terrorism issue in its programmatic agenda in order to capitalise on a range of recent attacks. In the wake of the November 2015 Paris terror attacks, Marine Le Pen placed the incident within the broader context of a value conflict labelling the attackers as 'enemies of liberty' (Le Pen, 2015b). Several months earlier, following the Charlie Hebdo attacks in January 2015, a FN flyer described the 'Islamist danger' as a 'consequence of massive immigration' (Front National, 2015). These statements are representative of key themes of the FN's reaction to terrorism. First, it portrays Islamic terrorists as outsiders; and second, as a danger to the French nation because they are hostile to its defining values such as liberty. The party frames terrorism as an external problem regardless of whether terrorist attacks were perpetrated primarily by French citizens (as, for example, in the 2015 attacks), and as a clash of values that 'we' as a nation can resolve by containing the entry of the foreign 'other', who poses a threat to our national identity and security. How may we explain the FN's framing of terrorism?

We argue that through this choice of rhetoric, the FN attempts to solve the abovementioned dilemma, i.e., the difficulty of avoiding racialized, descent-based exclusionary rhetoric while addressing the fact that many attacks have been perpetrated by native-born residents or citizens. Specifically, our argument is that the FN addresses this dilemma by portraying terrorism as a breach of the French liberal democratic consensus. Drawing on literature that has examined the ways in which far-right parties use civic nationalism in their programmatic agendas (Halikiopoulou et al. 2013), we develop a more detailed, fourpronged typology of nationalism (ethno-racial, cultural, political-civic and economic) and posit that the FN has increasingly drawn on a conception of a national solidarity pact, grounded in cultural and political-civic terms, to which certain immigrant groups do notand should not-belong. Therefore, (1) nationalism provides the ideological link between 
terrorism and immigration; and (2) changes in FN party framing of terrorism across time can be understood in terms of changes in the type of nationalism employed by the party. The party has increasingly adopted this approach over time as it has become more incentivised to shift away rhetorically from clear associations with racism, fascism and predominantly ethnic nationalism in order to augment its electoral appeal. This shift is consistent with the party's move towards French Republicanism since Marine Le Pen took over from her father (Betz 2013) and fits with the adoption of laïcite in the party's programmatic agenda, which allows it to portray anti-Islamism as a secular principle rather than racist exclusion.

In order to ground our argument empirically, we carry out content analysis of FN articles and press releases published in reaction to seven terrorist attacks on French soil during the period 1986-2015. We find that (1) the salience of the terrorism issue increases in FN materials during the month following an attack, though there are variations between years. (2) Materials that deal with terrorism consistently link security to nationalism, presenting immigration as the core cause of terrorism and as a fundamental violation of national cohesion. (3) Our analysis identifies both change and continuity across time. Change occurs in that documents published under the leadership of Jean-Marie Le Pen draw on all four categories of nationalism, while documents published under the leadership of Marine Le Pen draw almost exclusively on the cultural and political-civic categories. There is continuity, however, in that throughout the period examined, cultural and political-civic nationalism framing is predominant, providing the overarching rationale of the FN across time. We also examine four manifestos (1997, 2002, 2012 and 2017) qualitatively to corroborate our findings.

\section{Nationalism and the far right}

Nationalism, understood as a quest to attain and maintain the sovereignty, unity and identity of a nation (Breuilly 2005), is fundamentally a political principle (Gellner 1998; Breuilly 2005). The pursuit of national sovereignty connects directly to questions about immigration, as at the core of sovereignty lie in-group and out-group dynamics. Because nationalism is a form of a solidarity pact (Wimmer 1997: 29) between the members of the national-political unit, it delineates clear criteria of excluding those who are not part of the pact, i.e. the out-group. Because of its 'thin' nature, or in other words its inability to provide answers to domestic, social issues (Freeden 1998), nationalism is chameleon-like (Hall 2011): i.e., it 'sticks' to other ideologies, thus offering different justification of national belonging and exclusion depending on the political actors that employ it.

Nationalism is not just a shared feature of far-right party programmatic agendas, but more importantly the key justification to all their policy positions (Halikiopoulou and Vlandas 
2016; Vasilopoulou and Halikiopoulou 2015). Far-right parties offer 'nationalist solutions' (Vasilopoulou and Halikiopoulou 2015) to all societal issues. They own the immigration issue (See e.g. Ivarsflaten 2008; Lucassen and Lubbers 2012; Van Spagne 2010) and use nationalism to justify their strict and exclusionary position: anyone who is not a member of the in-group should be excluded from 'our' national solidarity pact.

The far right tends to be more closely associated in the literature with nativism (Mudde, 2007), i.e. an exclusionary or ethnic form of nationalism that poses strict criteria of national membership defined by characteristics such as race, community of descent, creed and language (Halikiopoulou et al., 2013). This literature suggests that far-right parties tend to adopt ascriptive criteria for defining and excluding the out-group. Some studies, however, have shown that civic nationalism, i.e. a more inclusionary form of nationalism that poses voluntaristic criteria of national membership and emphasises deliberate commitment (Zimmer, 2003), may also be associated with the agenda of far-right parties (Koopmans and Statham, 1999; Halikiopoulou et al., 2013). This research draws on the 'ethnic-civic' distinction in the study of nationalism (Smith 1991; Kohn 1944) to show that recent changes in the agendas of some European far-right parties may be explained by their attempts to shift the boundaries of national belonging by justifying exclusion on the malleability of toleration rather than race or colour. The conceptualisation of nationalism as either ethnic or civic is helpful for understanding the different far-right variants, including extreme and radical, which differ in terms of their relationship with democracy, the extent to which they employ violence, and the extent to which they maintain ties with fascism. On the one hand, the extreme variants, which reject democracy, employ violence and maintain ties with fascism, tend to adopt ethnic nationalist rhetoric. On the other hand, the radical variants that accept procedural democracy (Mudde 2010), refrain from violent practices and distance themselves from fascism (Halikiopoulou and Vlandas 2016) tend to adopt a civic nationalist rhetoric (Halikiopoulou et al. 2013).

This assessment is in line with the arguments made by research that distinguishes between the 'old' and 'new' far right (Golder 2003) and contends that the more successful far-right parties in Europe are those that have abandoned connections with the old inter-war right in favour of a new ideological basis. While the 'old' far-right parties, which tend to be branded as 'extreme', reject both substantive and procedural democracy and maintain ties with fascism, 'new' far-right parties tend to be described as 'radical' or 'populist radical' because they accept procedural democracy, and in their attempt to appear more legitimate distance themselves from explicit racism. 


\section{Addressing terrorism}

How does this 'civic normalization strategy' affect far-right party positions on terrorism? Political parties need to address both the issues over which they have ownership, as well as those where their stance may be less well established but that have salience among voters. Strategically, then, it benefits them to link salient issues to those over which they have ownership. As noted above, far-right parties own immigration, which is a multi-faceted issue. Cultural grievances over immigration centre on perceptions that immigrants erode the national way of life and threaten national identity and established social norms. Immigrants of Muslim origin are often portrayed as especially threatening to the dominant value consensus of European countries and least likely to assimilate (Rydgren 2008: 745). Such cultural grievances are pertinent within the context of an emerging post-materialist value cleavage (Hooghe and Marks 2017; Inglehart and Norris 2016), which pits those with universalist values against those who seek to maintain the national way of life. Economic grievances over immigration on the other hand are linked to perceptions that natives compete with immigrants for jobs, welfare and public services (See e.g. Hainmueller and Hopkins 2014; Mayda 2006; Lucassen and Lubbers 2012). This dimension is increasingly emphasised by far-right parties, which often link unemployment and economic malaise with immigration. A third related dimension is that of criminality and social unrest (Rydgren 2008; Burscher et al. 2015), as immigration is often presented as associated with high crime levels and even terrorism.

The increasing salience of the terrorism issue (Crabtree and Kluch 2016; European Commission 2017), then, compels far-right parties to connect terrorism to immigration. This is particularly the case for the FN given the number of terrorist attacks perpetrated on French soil in recent years. However, this opportunity is constrained by the fact that many perpetrators of terrorist acts are not necessarily immigrants but, often, second or third generation native-born citizens. Presenting terrorists as 'immigrants' constitutes a descentbased ethnic nationalism argument that, as the literature argues, does not benefit the far right electorally.

How does the far right address the terrorism issue? There is a large body of research that focuses on far-right party supply. This literature tends to examine the broader framework of Political Opportunity Structures (POS) (e.g. Mudde 2007) and/or Discursive Opportunity Structures (DOS) (e.g. Koopmans and Statham 1999), focusing on the evolution of these parties' agendas - for example, the FN's 'de-demonization' strategy (e.g. Ivaldi 2015; Stockemer 2017; Betz 2013) and the 'normalisation' of its rhetoric (e.g. Mayer 2015). There is also some recent work focusing on demand-side dynamics and the ways in which terrorism affects political participation and voting behaviour (e.g. Vasilopoulos 2018; Vasilopoulos et al. 2018). While, therefore, some of this literature 
touches upon the terrorism issue, the ways in which far-right parties - the FN in particular - specifically address this dilemma remain under-studied.

This article concentrates solely on the terrorism issue. It systematises the framing of terrorism in the programmatic agenda of the $\mathrm{FN}$ by focusing on nationalism. Approaching the FN's programmatic agenda through a nationalism framework presents a distinct theoretical advantage because it allows us to conceptualise the shift in the party's programmatic agenda through a concrete and nuanced theoretical framework that takes into account the different ways in which exclusion of the out-group can be legitimated. We argue that the FN links the terrorism issue to immigration by portraying the former as a breach of the liberal democratic consensus dominant in France. It does this by increasingly distancing itself from ethnic, descent-based or ascriptive forms of nationalism, which allows it to shift away rhetorically from clear associations with racism and fascism. It has adopted, instead, more voluntaristic conceptions of nationalism, which allow it to portray the contract between state and citizens as the defining feature of national belonging. Our argument is consistent with literature, which argues that far-right parties are increasingly adopting civic narratives in their programmatic agendas (Halikiopoulou et al. 2013). It is important to note that this article makes an argument about the FN in particular, which it is able to test empirically. An empirical test of the argument on other cases is outside the scope of this article. However, the observation that claims put forward here are consistent with the broad supply-side literature mentioned above opens up avenues for future research.

\section{The Front National: nationalism, immigration and the 'préférence nationale'}

The establishment of the FN in 1972 brought together different strands of right-wing extremism (Stockemer 2017), which had been marginalised and discredited in the French political system after the end of the Second World War. Since its establishment, the party has experienced varying levels of success. The evolution of the its discourse across time, and importantly its transition from the leadership of Jean-Marie Le Pen to Marine Le Pen, has been marked by both continuity and change. The party shifted from representing 'a rallying point for the various strands of traditional French right-wing extremist nostalgia' (Betz 2013: 2) including Vichy and l'Algerie française during Jean-Marie Le Pen's leadership to the embracing of French Republicanism and laïcité after Marine Le Pen took over. Despite various changes in the party's discourse and programmatic agenda, however, the FN has remained since its establishment anti-immigrant. Specifically, the party has consistently opposed immigration, adopting a tough stance on multiculturalism and border control, and opposing dual nationality. Its anti-immigrant agenda may be best summarised by its policy of the 'préférence nationale', i.e. the premise that in France, the French must 
come first. This policy underpins the FN's stance on multiple issues, including welfare and citizenship policy, as the party supports strict limitations on immigrant access to public goods and welfare provisions such as health and unemployment assistance and protection.

During Jean-Marie Le Pen's leadership, the préférence nationale was pursued through an 'indirect racist discourse' in the FN's representation of a closed 'national identity' (Hainsworth 2008). This approach is what Taguieff (1985) terms 'cultural and differentialist neo-racism'. Jean-Marie Le Pen's FN was characterised by a rejection of Republican ideas, emphasising instead French cultural heritage (Betz 2013: 3) - and its connection with Royalist Catholicism - and common destiny. This position has shifted since Marine Le Pen took over from her father, as she has pursued a strategy of 'dedemonization' of the party and a 'softening of its rhetoric' (Mayer 2013; Ivaldi 2015) in an attempt to transform it into a 'catch-all party of protest' (Betz 2013: 2). This process has included a shift of emphasis from préférence to priorité nationale in order to disassociate the party from the negative connotations of Jean-Marie Le Pen's rhetoric and create distance from the party's reputation for exclusionist discrimination (Alduy and Wahnich 2015).

The FN's economic policy has also changed significantly across time: from loosely corporatist ideas in the 1970s to free market in the mid-late 1980s supporting tax cuts and privatisation; then in the 1990s moving towards economic protectionism (Hainsworth 2008). During the leadership of Marine Le Pen, the party significantly shifted its economic platform from a predominantly right-wing to a left-wing stance (Ivaldi 2015). This shift has also been accompanied by a strong emphasis on social issues (Betz 2013) and is related to an attempt by Marine Le Pen to make the party appear credible to deal with rising unemployment and economic hardship (Bastow 2018). Marine Le Pen's claim to be the advocate of 'the silent majority' (Betz 2013) is a clear appeal to those left behind by modernisation, i.e. the economically insecure who have been marginalised by globalisation, technological change and other societal shifts.

Her transformation of the party's programmatic agenda is underpinned by an overall turn towards support for French Republicanism (Bastow 2018; Betz 2013): i.e. the promotion of the FN as 'the only genuine defender of the ideals reflected in French republicanism, but betrayed by the political establishment' (Betz 2013: 3). This turn has helped the party increase its popularity (Bastow 2018), reaching a broader electoral base that captures 'younger' votes (e.g. Stockemer and Amengay 2015) and achieving a closing of the farright gender gap in France (Mayer, 2013; Mayer, 2015).

The turn towards Republican restoration, sovereignty and support of lä̈cité - understood through the prism of nationalism - we argue, lies at the core of understanding how the FN 
justifies its position on terrorism. The key to this strategy is the presentation of radical Islam as antithetical to the principles of laïcité: Marine Le Pen has repeatedly suggested that it is not Islam per se that runs counter to the principles of the French Republic, but rather Shariah, because this doctrine constitutes 'the intrusion of the religious realm into the secular realm' (Betz 2013: 10). The FN's new commitments to the French Republic, therefore, are used to justify the party's position on terrorism by portraying France as under the threat of Islamization and Islamic terrorism in particular (Bastow 2018: 22).

There is a debate in the literature about the extent to which Marine Le Pen's populist turn constitutes a fundamental turning point for the party's identity or is merely a rhetorical shift (see Betz 2013; Bastow 2018; Stockemer 2017; Alduoy and Walnich 2015). However, the focus of most works is on the party's agenda more broadly. We focus on this question specifically with regards to the terrorism issue. The aim in the sections that follow is to examine the continuity and changes in the FN's position on terrorism across time through an analysis of how the party uses nationalism to justify its stance. This analysis complements works that study the FN's transition from the leadership of Jean-Marie Le Pen to Marine Le Pen, and especially arguments that focus on the party's shift towards French Republicanism and laïcité, its position on religion more broadly, and Islam more specifically. Our argument is that we can understand this position through an analysis of the different forms of nationalism employed by the party.

\section{Data and methods}

To ground our argument empirically, we carry out content analysis of FN articles and press releases published in reaction to seven terrorist attacks on French soil during the period 1986-2015. While these terrorist attacks differ in terms of the group that perpetrated them and in their scale (i.e. number of fatalities), they are comparable because all were committed by militant Islamic individuals or groups, all were carried out on French soil and all had fatalities. We commence our analysis in 1986, which is the date of the first fatal terrorist attack to take place on French soil against civilian targets following the creation of the FN's first regular publication in the form of a semi-monthly magazine, La Lettre de Jean-Marie Le Pen, which constitutes the first systematically accessible party material. Between 1985-1995 this magazine was published under the title La Lettre de Jean-Marie Le Pen and from 1995-2008 as Français d'abord. For the attacks of 2012 and 2015, we have analysed all press releases from the FN's website. Table 1 indicates the date and location of the attacks, the perpetrators, the FN materials coded and, in order to properly understand the context of the FN's reaction, the dates at which the perpetrators became publicly known.

Table 1: Fatal Terrorist Attacks on French Soil, 1986-2015 ${ }^{\mathrm{ii}}$ 


\begin{tabular}{|l|l|l|l|}
\hline $\begin{array}{l}\text { Terror } \\
\text { Attack }\end{array}$ & Perpetrator & Perpetrator known & FN Documents \\
\hline $\begin{array}{l}\text { 13 Nov. } \\
\text { Paris }\end{array}$ & ISIS & 14. Nov. 2015 & $\begin{array}{l}\text { Press releases from } \\
\text { website (14 Nov. }-14 \\
\text { Dec. 2015) }\end{array}$ \\
\hline $\begin{array}{l}\text { 7-9 Jan. } \\
\text { 2015 } \\
\text { Paris \& } \\
\text { outskirts }\end{array}$ & $\begin{array}{l}\text { Cherif and Said Kouachi, } \\
\text { Amedi Coulibaly } \\
\text { (Unaffiliated; Coulibaly } \\
\text { claimed ISIS ties) }\end{array}$ & Jan. 8/Jan. 9 2015 & $\begin{array}{l}\text { Press releases from } \\
\text { website } \\
\text { (8 Jan. - 8 Feb. 2015) }\end{array}$ \\
\hline $\begin{array}{l}\text { 19 Mar. } \\
\text { 2012 } \\
\text { Toulouse }\end{array}$ & $\begin{array}{l}\text { Mohammed Merah } \\
\text { (Unaffiliated, claimed Al } \\
\text { Qaeda ties) }\end{array}$ & 21 Mar. 2012 & $\begin{array}{l}\text { Press releases from } \\
\text { website } \\
\text { (22 Mar. - 22 Apr. 2012) }\end{array}$ \\
\hline $\begin{array}{l}\text { 3 Dec. 1996 } \\
\text { Paris }\end{array}$ & $\begin{array}{l}\text { Armed Islamic Group } \\
\text { (GIA) } \\
\text { (Algeria) }\end{array}$ & $\begin{array}{l}\text { Quickly attributed to } \\
\text { 'Islamists', by 5 Dec. } \\
\text { 1996, government } \\
\text { suspected GIA }\end{array}$ & $\begin{array}{l}\text { Français d'abord 1 Dec. } \\
\text { 1996 } \\
\text { Français d'abord 15 } \\
\text { Dec. 1996 }\end{array}$ \\
\hline $\begin{array}{l}\text { 6 Oct. 1995 } \\
\text { Paris }\end{array}$ & $\begin{array}{l}\text { Armed Islamic Group } \\
\text { (Algeria) }\end{array}$ & $\begin{array}{l}\text { Correctly assumed } \\
\text { immediately, } \\
\text { confirmed with } \\
\text { capture of leader early } \\
\text { Nov. }\end{array}$ & $\begin{array}{l}\text { Français d'abord 15 } \\
\text { Oct. 1995 } \\
\text { Français d'abord 1 Nov. } \\
\text { 1995 }\end{array}$ \\
\hline $\begin{array}{l}\text { 25 July } \\
\text { 1995 } \\
\text { Paris }\end{array}$ & $\begin{array}{l}\text { Armed Islamic Group } \\
\text { (Algeria) }\end{array}$ & Sept. 1995 & $\begin{array}{l}\text { Français d'abord 1 Sept. } \\
\text { 1995 } \\
\text { (Note: not published in } \\
\text { Aug.) }\end{array}$ \\
\hline $\begin{array}{l}\text { 17 Sept. } \\
\text { 1986 } \\
\text { Paris }\end{array}$ & $\begin{array}{l}\text { Fouad Ali Saleh and his } \\
\text { network } \\
\text { (Iran) }\end{array}$ & Feb. 1987 & $\begin{array}{l}\text { La Lettre... 1 Oct. 1986 } \\
\text { La Lettre...15 Oct. 1986 }\end{array}$ \\
\hline
\end{tabular}

We examine a total of 341 documents. These include 121 documents published during the years of Jean-Marie Le Pen's leadership and 220 under the leadership of Marine Le Pen. We coded FN publications from the month following each attack in order to gauge the party's direct reaction and framing of the issue in the wake of attacks. ${ }^{\text {iii }}$ First, we measure the extent to which the FN places an emphasis on the terrorism issue by counting the number of articles within each set of materials published in the wake of each terrorist attack that refer to terrorism and/or its link with immigration and security. Second, we code these articles (that refer to terrorism and/or its link to immigration and security) in accordance with our four categories of nationalism as to establish 1) Whether the FN frames terrorism in terms of nationalism; and, if so, 2) which category of national 
belonging the FN has emphasised following each terrorist attack. This approach allows us to capture the change in the party's position on terrorism over time. It is important to note that while individual party members' positions may vary, these documents reflect the official stance of the party, and we have coded them as such.

For purposes of operationalisation, we identify four categories of nationalism: ethnoracial, cultural, political-civic, and economic. This four-pronged typology permits us to go beyond the dichotomous ethnic-civic model prominent in the nationalism literature in order to understand the subtleties of shifting political discourse. We develop our categories building on past works, which have theorised and operationalized nationalism and/or national identity in accordance with various dimensions (see e.g. Kaufmann 2002; Thomas 2013; Zimmer 2003; Eger and Valdez 2018; Halikiopoulou et al 2012; Larsen 2017; Reeskens and Hooghe 2010). It is of note here that our focus is on types of nationalism, i.e. on the ways in which the political quest for sovereignty and exclusion is justified, as opposed to types of national identity understood as a process of 'continuous reproduction of the patterns of values, symbols, memories, myths and traditions that compose the distinctive heritage of nations and the identification of individuals with that heritage' (Smith 1991). What we are interested here is the way in which far-right parties justify exclusion through their arguments about nationalism and immigration.

Ethno-racial nationalism is grounded in immutable traits. It defines national membership through ascriptive criteria, in which national identity is fixed and based on some combination of ancestry, phenotype/'race', ethno-religious identity, and speaking the national language as one's mother-tongue. Cultural nationalism draws on traits that are difficult to change but are subject to socialisation. This category thus includes references to cultural-religious identity, high-functioning proficiency in the national language, family structures and institutions, and mores and values, more broadly. Political-civic nationalism draws on voluntarist criteria of inclusion, including the socio-political values system and institutions. Markers of this conception include references to democratic institutions, rule of law, rights and responsibilities of citizenship, and sovereignty (including territorial integrity and security). Finally, economic nationalism is also participation-based and institutional, but the focus is on financial institutions. This conception of nationalism can be observed in references to labour market institutions, the work ethic, taxation, and welfare state redistribution.

Our coding was carried out as follows: the first author coded all 341 documents and the second coded a random sample. This included, first, a representative sample of 40 units for a pilot test; and second, a $20 \%$ random sample of the remaining documents. Disagreements centred mainly around the coding of certain documents within either the 'ethnic' or 'cultural' categories and as a result we refined our operationalization by coding specific 
references to national origin as 'ethnic' when the context implied some immutability of traits. There were also few instances where we debated whether immigration was framed as a 'cultural' or a 'political-civic category', and agreed that we would categorise references to immigration as 'political-civic' unless there was a specific association of immigration with cultural practices and values.

We also qualitatively examine a sample of manifestos across time to cross-check our findings: manifestos vary in size and format, and most manifestos do not contain specific sections on terrorism. Unlike the press releases, manifestos do not refer to specific terrorist attacks (with few exceptions, e.g. 2017). We therefore do not conduct systematic coding of manifestos. The fact that terrorism does not feature as a programmatic issue in and of itself in the manifestos does not diminish its importance. Rather, it serves as a backdrop against which other issues are framed. For this reason, we deem qualitative analysis of the manifesto materials that do mention terrorism as more appropriate. Identifying instances of our four categories of nationalism, we determine whether this corroborates the findings from our coding above. Specifically, we have examined four manifestos available on Manifestos Agendas Project: 1997, 2002, 2012 and 2017.

\section{Empirical analysis}

\section{Increased salience of terrorism in FN materials}

We begin by gauging the prevalence of the terrorism issue in FN materials published immediately following deadly attacks. Figure 1 shows the frequency of mentions of terrorism (and/or its link to immigration and insecurity) in the month after each attack. 


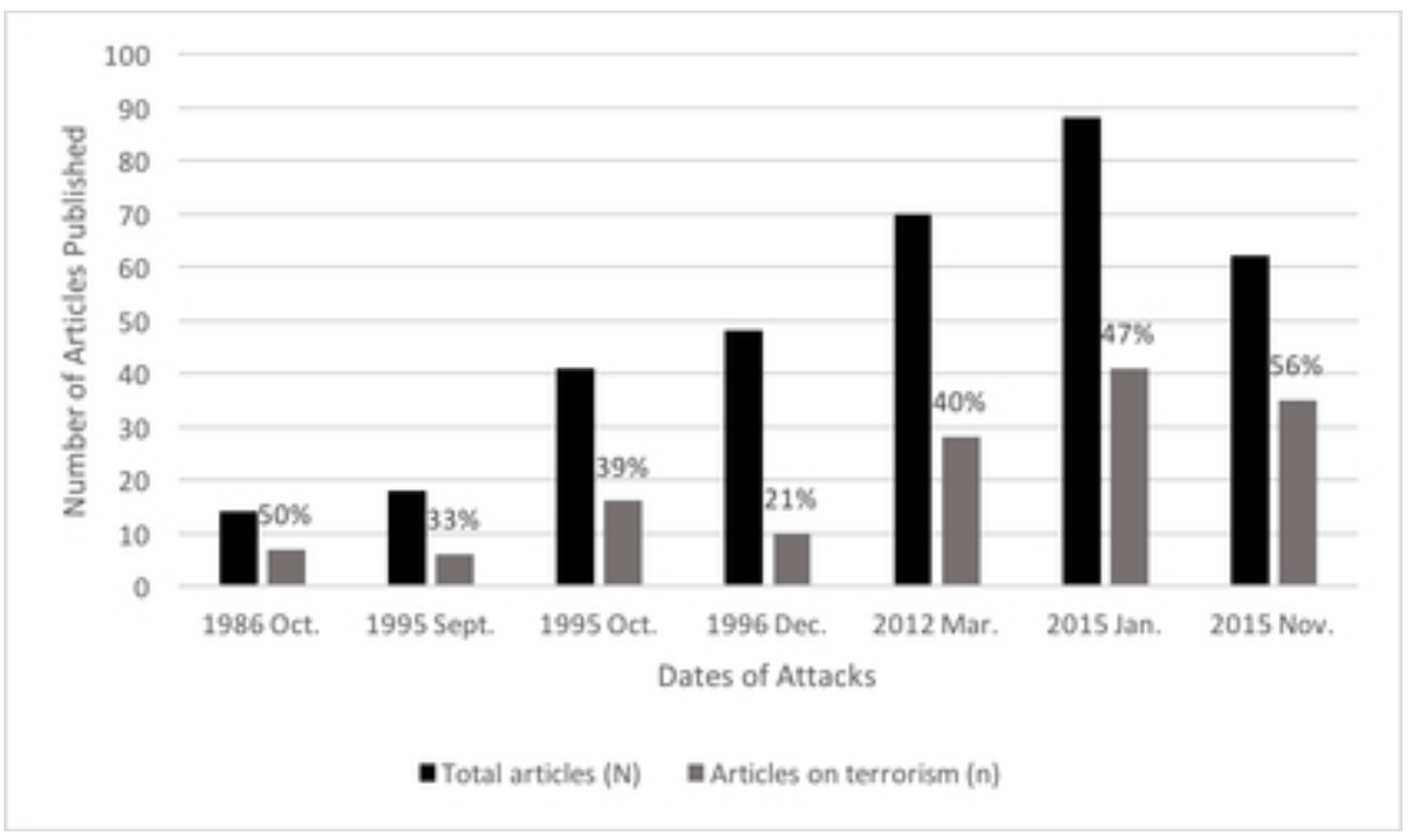

Figure 1: Prevalence of the terrorism issue in FN materials published in the wake of terror attacks, 1986-2015

The quantity of published materials increases over time, as the FN's magazine became progressively longer, and then as the internet replaced more costly, slower traditional methods of publication. One would expect that the month following an attack would be a period of heightened attention to the topic. We find that indeed the subject is prevalent, yet the frequency varies over time. These variations coincide with differences in the context of the attacks themselves. For instance, the somewhat smaller percentage of articles focusing on the terrorism issue in September 1995 (following the July attack) may reflect the lag in the publication schedule (as the magazine was not published in August). The December 1996 numbers may reflect the prevalence of year-end and beginning-of-year business (notably including the multi-page FN calendar provided in the magazine). Among the more recent materials, the focus on the presidential election of 22 April 2012 may partly account for the slightly diminished focus on the terrorism issue in March 2012. It is also possible that the more narrowly targeted nature of this attack - committed by a lone individual, rather than a terrorist organisation - against a specific population (Jewish people), rather than indiscriminately - drew less attention. The increased salience of the terrorism issue in November 2015 FN materials matches expectations, based on the exceptional scope and carnage of the attacks. 
Having measured the prevalence of terrorism in the FN materials, we proceed to examine the particular articles that discuss terrorism in order to identify how the nationalism framework is employed over time. We group the documents analysed into two eras: the period in which the FN was headed by Jean-Marie Le Pen (covering the terrorist attacks from 1986-1996) and the Marine Le Pen era for the attacks of 2012 and 2015.

Overall, our analysis reveals that the FN publications that mention terrorism consistently place it within the nationalism framework, connecting security, nationalism and immigration. The party depicts immigration as the core cause of terrorism: the entry of outsiders constitutes a rupture in the national solidarity pact. The idea that terrorism is more than anything a product of immigration and France's 'ineffective' immigration policy is a common theme in all documents. Placing terrorism within the broader context of immigration and national security, the FN portrays it as an external problem, perpetrated by an 'invasion' (Le Pen 1996) of hostile immigrants who come to France seeking to cause damage because their cultural values are antithetical to 'ours'. By extension, the proposed FN solution is to keep outsiders out and stand together as a nation against the external threat. This is because 'it is thus not about Islamic terrorists that we need to speak, but truly about immigrant terrorists and the immigrant war' (Le Pen 1995b). The party's main leitmotif throughout the thirty-year period studied here is twofold: 1) Terrorism cannot be contained 'without controlling the comings and goings of foreigners in our territory' (Le Pen 1996); and 2) While terrorism is an external problem, it has been facilitated domestically by the weak political elites who fail to contain it.

Our findings, however, also indicate that there has been a change in the party's stance over time: whereas under Jean-Marie Le Pen's leadership the FN employs all four categories of our nationalism framework, under Marine Le Pen the FN draws almost exclusively on the cultural and political-civic categories. We find that in the later documents there are almost no references to the ethno-racial category, reflecting a shift in the way the party frames nationalism. Religion in a cultural sense, as opposed to ancestry, has become the lens for 'otherising' immigrants. This finding is in line with literature that deals with the FN, and more specifically Marine Le Pen's 'de-demonization' or 'normalisation' strategy (Ivaldi 2015, Mayer 2015). Our nationalism framework allows us to examine this shift beyond just a rhetorical 'normalisation' or 'de-demonization' and to theorise it as part of a generalisable trajectory that far-right parties follow. In this sense, we are consistent with literature that distinguishes between the changing rhetoric of the 'old' and 'new' far right (e.g. Golder 2003) as well literature that draws on the ethnic-civic distinction in the study of nationalism (Koopmans and Statham 1999; Halikiopoulou et al. 2013), which argues that far-right parties are increasingly abandoning ethnic nationalism frames in favour of a 
more civic-oriented rhetoric. In our analysis the FN remains firmly within the far-right category, while utilising an increasingly cultural and political-civic rather than ethnic type of nationalism.

The rhetorical shift, however, is not as clear-cut as we might expect. While Jean-Marie Le Pen did, indeed, employ more frequent and more explicit ethno-racial framing of national identity, he also emphasised cultural and political arguments. Most often he and the other FN officials who contributed to the party's magazine framed their exclusionist policies in cultural, political-civic, and - particularly in the oldest documents of this study - economic terms. This finding is in agreement with the thesis regarding Jean-Marie Le Pen's 'indirect racism' and 'differentialist neo-racism' (Hainsworth 2008; Taguieff 1985).

Figures 2, 3 and 4 below illustrate the extent to which the FN has drawn upon each category of nationalism between 1986-2015. Figure 2 shows the numbers of occurrences of the different framing categories in articles dealing with terrorism following each attack. The ' $n$ ' listed for each date refers to the number of articles that mention terrorism issues, and the ' $N$ ' refers to the total number of articles published at that time. Figure 3 shows the percentage of articles pertaining to terrorism that invoke the different categories of nationalism in the wake of each attack. Each article could count toward multiple categories and does not represent a unique count. Figure 4 does the same as Figure 3, but with the articles grouped into two sets: those published under Jean-Marie Le Pen's leadership and those published during the tenure of Marine Le Pen.

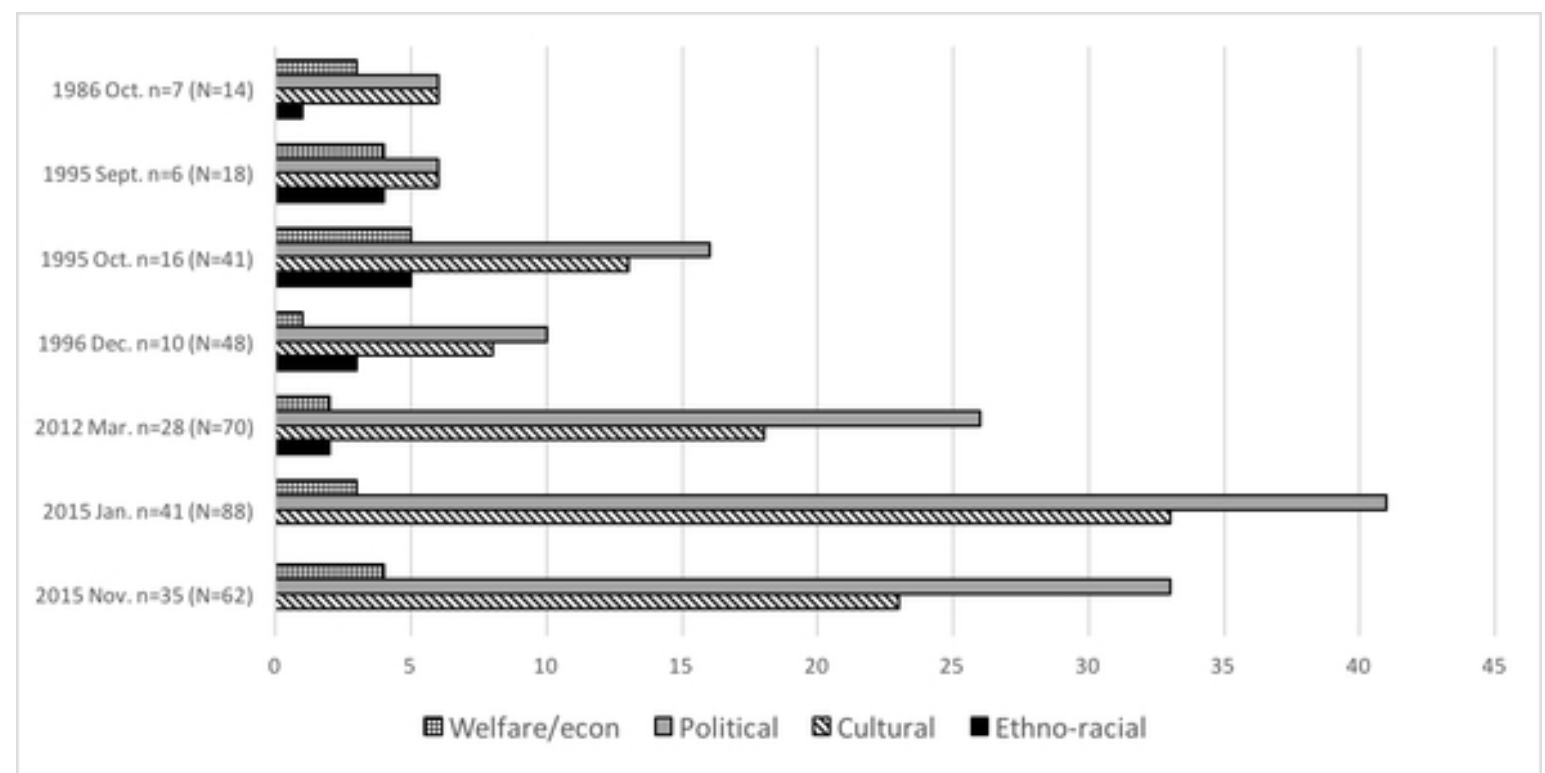

Figure 2: Categories of nationalism in FN materials on the topic of terrorism, 1986-2015 


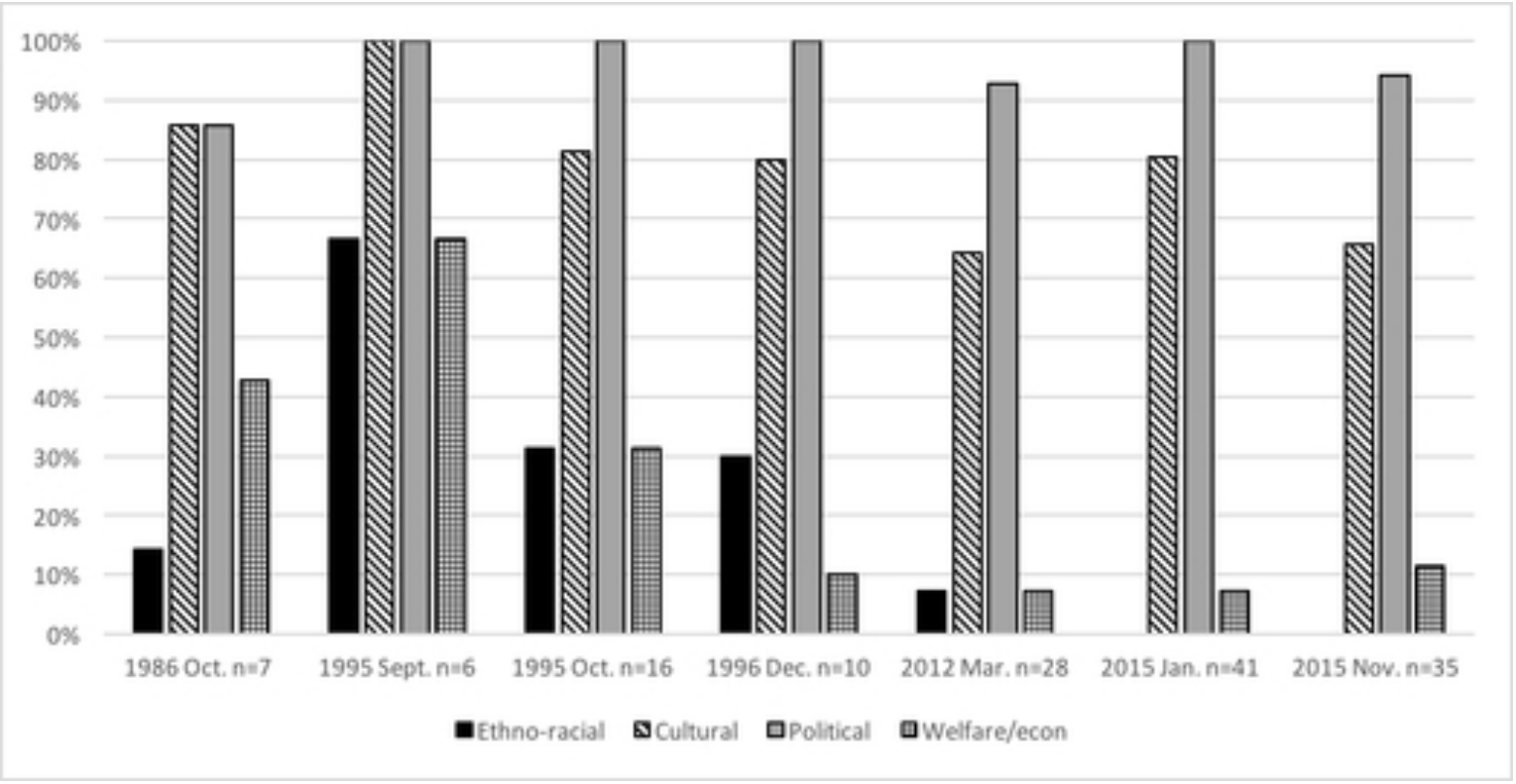

Figure 3: Proportion of categories of nationalism in FN materials on the topic of terrorism, 1986-2015

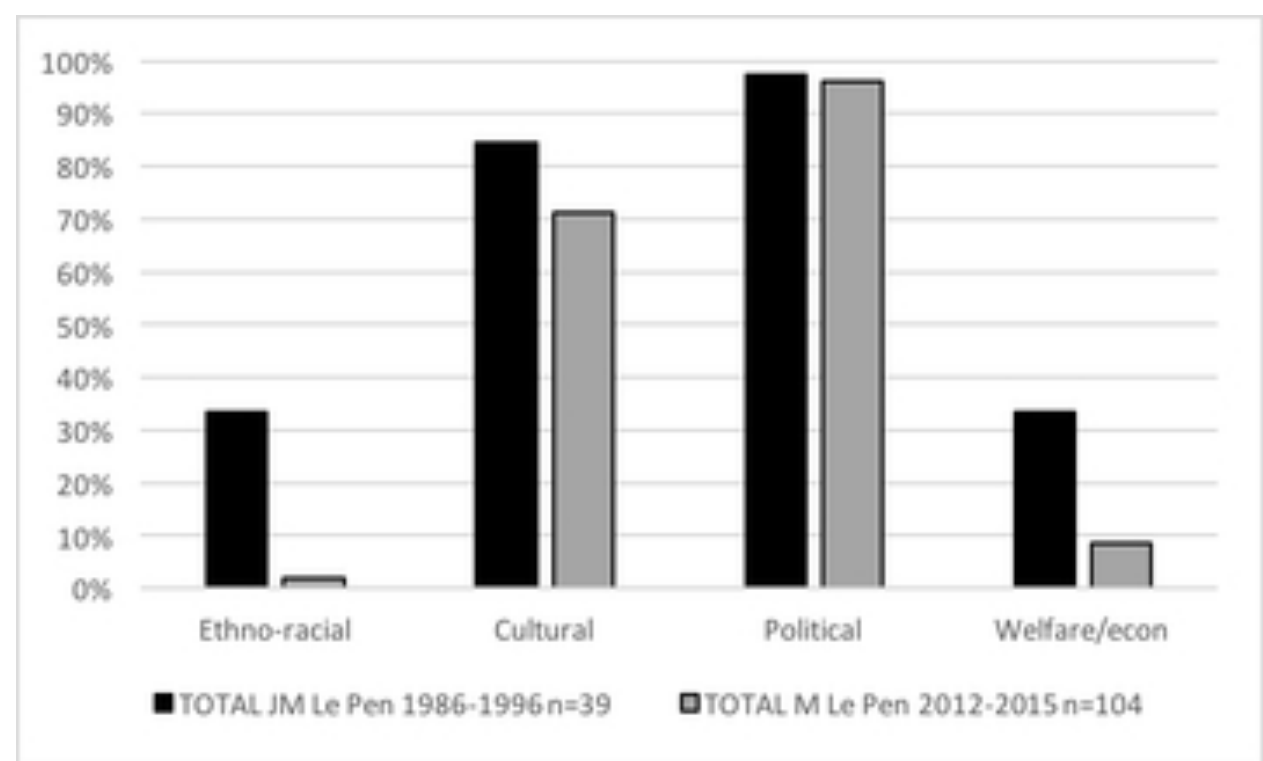

Figure 4: Proportion of categories of nationalism in FN materials on the topic of terrorism grouped by period of leadership, 1986-2015 
Documents published under the leadership of Jean-Marie Le Pen vociferously reject the 'racist label' that they contend was put upon the FN by opposing parties and media. In Français d'abord the party argues that FN leaders discuss immigration and designate people as French 'without distinction of colour, race or religion' (Descaves 1996). However, the documents of this time do contain some more explicit racist claims, which they frame in terms of nationalism. For instance, statements such as 'France needs French, not immigrant, blood' (Descaves 1996); 'alien populations are exporting their civil wars to France' (Le Pen 1995a); and 'the construction of places of worship facilitates the establishment of alien populations' (Français d'abord 1995b) all have explicit ethno-racial connotations.

Such references become more prevalent from September 1995 onwards, after the series of attacks and the concomitant riots in the banlieues ${ }^{i v}$ that year. Increasingly emphasising the immutability and the ethno-racial specificity of behavioural traits, comments such as 'it is impossible to change people's nature' (Le Pen 1995c: 3) become more frequent. The consequence, according to these materials, of this 'natural' difference between people is that 'migrants cannot and will not integrate' (Le Pen, 1995c: 3). This argument is that minorities pose a fundamental threat to the very existence of multicultural countries. The party also emphasizes the perennial nature of the French nation and its identity, which has existed for 'over one thousand years' (1995c: 3).

In these older documents, cultural arguments also often have explicit ethno-racial connotations, as in the notion that someone can be born in France, yet be classified as an 'immigrant' despite jus soli citizenship laws. According to Français d'abord, the birth of large numbers of 'immigrants' in France every year 'is leading to the "Lebanonisation" of our country' (Français d'abord 1995a: 5). At times, however, ethno-racial connotations can be far more implicit, the emphasis being instead primarily on the cultural basis of nationalism. For example, some documents justify the FN's stance against the building of mosques in France by warning against the rise of the political influence of Islam and 'Islamic terrorism': 'While preserving the right to freedom of worship, the FN is the only political movement to fight to safeguard French identity by proposing to stem the rise of Islam and its political influence in our country' (Français d'abord 1996). The argument here is a 'clash of civilisations' cultural thesis (Huntington 1997), which holds that 'populations whose cultures and religions are diametrically opposed to those of France cannot adopt French values' (Gollnisch 1996). The FN links this perceived incapacity to assimilate to laïcité: 'France is a secular and republican state which, though it respects 
freedom of worship, must not promote a religion. Indeed, the gift of municipal land will encourage establishment of the Islamic religion, which is incompatible with French laws, traditions, and way of life' (Le Pen 1995b; Français d'abord 1995b).

In addition to ethno-racial and cultural nationalism arguments, there is an overwhelming prevalence of references to political-civic nationalism in these documents. The justification of this type of argument is again the problem of assimilation: we exclude, not because these people are inherently different or inferior, but rather because they hold illiberal beliefs. This rationale has both a cultural and political dimension. The cultural dimension was discussed above: the underlying values immigrants hold are seen as antithetical to French values. The political dimension is the perceived hostility towards French democratic institutions. Security is an important theme for nationalism. This theme is also important in the FN's party competition strategy. The materials contain abundant references to the poor leadership of those in power who fail to ensure the security of the country: ' $[\ldots]$ it is clear today that the presence on our soil of several million nonEuropean foreigners who have different customs and traditions, and who refuse any integration constitute a danger that everyone can see except apparently for the cold-footed politicians still shivering under the control of the supposed "anti-racist" lobby" (Le Pen 1995b).

The older documents embrace authoritarianism as a means of ensuring political solidarity and securing the nation. They explicitly support strict measures for fighting terrorism, such as the death penalty against 'criminals directed from afar by the external enemy [... who act] with impunity against our compatriots, our wives, our children' (Le Pen 1986). This focus on the death penalty is connected to broader arguments about the decline of order and discipline: 'the danger is not so much that of being attacked $[\ldots]$ as it is having to face terrorism in a democracy where discipline has been on the decline for decades' (quoted in La Lettre de Jean-Marie Le Pen 1986).

Finally, there are also frequent references to the economic nationalism category of framing in the older documents. In these documents unemployment is a consistent theme, which Le Pen explicitly connects to immigration. For example, the September 1995 issue of Français d'abord shows a cartoon that depicts a bomb with a lit fuse on which is written 'unemployment + immigration'. This image illustrates an article about terrorism, war and instability being imported from the Middle East (Français d'abord 1995a: 4). The recurring rhetoric is that immigrants are taking away French jobs and are drawn to France to access social security and benefits. The FN argues that limiting benefit access to the French will help solve the immigration problem and by extension the terrorism problem (Descaves 1996). These themes also connect to Le Pen's idea of 'La guerre civile' (1995c), 
presenting the banlieues as a lawless state-within-a-state where immigrant groups maintain their culture and plan hostile acts towards a France that they reject.

\section{2-2015 Marine Le Pen Era Documents}

The newer documents also present terrorism as a breach of the social contract through the acceptance of mass immigration. Ethno-racial connotations are almost altogether absent in these texts. Among the newer documents released under Marine Le Pen's leadership of the FN, only two texts make such references to ethno-racial nationalism and these can be read as implicit. They include Marine Le Pen stating that Mohamed Merah is 'not a citizen like the others' by virtue of his Algerian origin and dual citizenship (Le Pen 2012) and a reference to immigrants as 'Barbarian hordes' (Arnautu 2012). This latter reference was made in a document written by then-Vice President of the FN, Marie-Christine Arnautu, as Marine Le Pen herself appears careful to frame her arguments almost exclusively in cultural and political terms, omitting any biological justifications of exclusion. Marine Le Pen further differentiates her leadership from that of her father by referring to 'French Muslims', distinguishing between radical Islamists and law-abiding Muslims who dutifully relegate their religious beliefs to the private sphere (Le Pen 2015b). Nevertheless, despite this qualification, the frequent mentions of radical Islam and the emphasis on its prevalence on French soil mean that most references to this religion associate it with a hostile threat to the nation.

While the newer documents mark a notable change from the older documents with regards to ethno-racial nationalism, there is a great degree of continuity over time concerning the cultural nationalism line of reasoning. Both the older and newer documents reflect the 'clash of civilisations thesis' in which some iterations of Islam are presented as incompatible with French values, politics and way of life: 'Not all of those we've opened our doors to have come to France with a love of our way of life [...] It only takes a dozen terrorists - some French in nationality, but not spirit [...] to take the lives of 129 of our countrymen' (Le Pen 2015b). The newer documents likewise emphasise links between immigration and radical Islamism via these so-called non-integrated communities, thereby indicating that these outsiders do not adhere to 'our' laws and social practices. For instance, in 2012 Marine Le Pen's press secretary, Dutheil de La Rochère, comments on Merah's flouting of cultural and legal customs by having been married in a religious ceremony without the preceding civil ceremony that French law requires. Such behavior is presented as 'hostile to France' and common among Muslims and their Imams (2012).

Similarly, the emphasis on the banlieues is still present, framed within a narrative that focuses on 'the clearly obvious link between mass immigration, communitarianism of populations of foreign origin, and the development of radical Islam' (Bay, 2015). The FN 
portrays the banlieues as 'forbidden estates [...] controlled by familial clans' where drug trafficking, organised crime and other forms of violence occur, connected to 'radical practice of the Muslim religion' (Thooris 2012). The party presents this as a broader security issue. Failing to address it will ultimately lead France to 'lose control of its internal security and to be regularly struck by terrorist acts' (Thooris 2012). Central to this argument, therefore, is the problem of assimilation, which is presented as a cultural issue, i.e., some members of these groups do not assimilate because their values are incompatible with those of France.

Arguments about culture are often directly connected to political arguments about respect for democratic institutions, the rule of law, and territorial sovereignty. As such they conform to the FN's party competition strategy. The party criticises the government's multiculturalist policies, whether regarding the construction of mosques or bilingual education policy, as exacerbating the problem of assimilation and thus facilitating terrorism as well as other forms of violence and social unrest (Maréchal-Le Pen 2015). This approach entails continuity over time also in terms of the political-civic nationalism category. The documents of both eras adopt a similar position and present terrorism as an external problem linked to immigration. Newer documents continue to promote strict measures on immigration: 'To effectively combat the jihadist threat, there are very strong political measures that need to be taken without delay: stripping citizenship from dual citizens who are involved in jihad, immediate suspension of the Schengen Agreement, in order to control our borders' (Philippot 2015). The newer documents also criticise then president François Hollande's policy of welcoming migrants, which they decry as a 'potential hidden path for terrorists to strike France' (Le Pen 2015a).

Newer documents further engage in party competition by using secularist arguments against the veil and Islam, thus attempting to appear more legitimate in the political system (mainstream parties use a similar argument against the hijab; Hutchins 2016; Scott 2007; Thomas 2012). These arguments connect with rhetoric that includes some Muslims within the French polity and shows them as needing protection from forces of radicalisation emphasising that 'our Muslim compatriots must no longer be hostage to radical Islamists' (Le Pen 2015b).

Finally, the economic nationalism category is not as prevalent in these materials as the cultural and political aspects of immigration. However, the newer documents still focus on the link between unemployment and immigration, as for instance, when discussing the banlieues, stating that - along with criminal activities - welfare subsidies constitute the primary source of income in these communities (Thooris 2012). Along with the security arguments, this approach contributes to the presentation of these groups as marginalised communities looking to profit from the system and in breach of the national solidarity pact 
as they seek to take full advantage of the collective goods of the state while remaining hostile to the national community as a whole and its values.

Our qualitative manifesto analysis corroborates these findings, demonstrating continuity and change in the FN's portrayal of terrorism. Earlier materials under Jean-Marie Le Pen's leadership emphasise stricter, more punitive policies in stark language: When they refer to terrorism, it appears under the heading of 'security' and broader mentions of crime. Advocating the death penalty for terrorists is a recurrent theme in these manifestos, as for instance calling for the 'reestablishment of the death penalty for assassins, terrorists, and major drug dealers' (1997).

Similarly, mentions of terrorism in the 2002 manifesto are spread across sections including 'Immigration', 'Security', 'Defence: Protecting our Homeland'. There are no references to specific terrorist attacks, but the overall message is in line with what we find in our other documents, where terrorism is treated in the same terms as other types of crime. Islam is only once, briefly connected specifically to terrorism (2002: 46), and is more often associated with the broader context of security, as under the heading, 'Organize the inversion of migratory flows': The presence of a massive immigrant population on our soil largely explains, as we have seen, the major delinquency that we are experiencing in France' (2002: 41). Similarly the 2012 manifesto makes only brief, passing mention of terrorism, perhaps because the issue was less salient in France at the time, given the length of time elapsed since the last attack on French soil that targeted the general public.

The 2017 manifesto is the only manifesto of the four that has a section dedicated to terrorism, which is hardly surprising given this salience of the issue around that time. This document corroborates our findings from the press releases, as it clearly establishes a link between terrorism and Islam, portraying the former as a breach of the social contract and both as a consequence of immigration. As such, the FN's suggestions for containing terrorism including closing down certain Mosques, stripping dual citizenship from people affiliated with Jihadists and dissolving any type of organisation linked with fundamentalist Islam (2017: 6).

\section{Conclusion}

This article has examined the evolution of the FN's position on terrorism through the prism of nationalism. Drawing on the ethnic-civic theoretical framework, and literature which has sought to operationalize nationalism, it has developed a typology to examine change and continuity in the party's programmatic agenda on terrorism under the leadership of both Jean-Marie and Marine Le Pen. We have argued that the FN has increasingly drawn 
on a conception of a national solidarity pact, grounded in cultural and political-civic terms, to which immigrants do not - and should not - belong. The party presents the 'immigration problem' as one of assimilation, created by immigrants who are both unable and unwilling to integrate because they hold beliefs antithetical to the values of the French nation. By presenting the 'other' as hostile because of their value system rather than their ethnicity, race, or ancestry, and therefore offering ideological rather than biological rationalisations for who belongs to the national solidarity pact, the party attempts to legitimate itself in the political arena. At the same time, however, we also find a great degree of continuity over time in that the cultural and political-civic categories are dominant throughout the period studied.

We have illustrated our argument empirically through an examination of FN materials over a period of thirty years. The findings from our analysis of FN publications within a month of each of seven fatal terrorist attacks against civilian targets on French soil from 19862015 indicate the following: first the terrorism issue is prevalent, though the frequency varies over time. Second, the documents that refer to terrorism place it within a national solidarity framework. The party portrays terrorism as a breach of the solidarity pact because of the entry of outsiders and their hostility to 'our values' and way of life. Third, there is both continuity and change within the thirty-year period of focus. On the one hand, the party is consistent in framing this national solidarity in predominantly cultural and political-civic terms. On the other hand, ethno-racial solidarity, which is more prevalent in the older materials, is largely absent after 2012. These findings are significant because, while consistent with existing literature on the 'normalisation' of the FN's rhetoric, they elucidate the nationalist mechanisms through which this normalisation occurs and ground it theoretically within the broader far-right framework.

Our contribution is both theoretical and empirical. In terms of theory, while there is a rich body of work that focuses on the programmatic agendas of far-right parties and their policy positions, there is very little work that focuses explicitly on their position on terrorism. With regards to the FN specifically, while existing literature discusses terrorism within the broader FN agenda, focusing on its 'normalisation' under Marine Le Pen, the party's positions on terrorism - and especially the ways in which these positions have shifted over time - remain understudied. This article has addressed both of these theoretical gaps by applying a nuanced nationalism typology framework in systematising the portrayal of terrorism in the programmatic agenda of the FN. We have examined the party's position on this issue through the prism of nationalism, arguing that the key to understanding the evolution of the FN's strategy is not just 'de-demonization' or 'normalisation', but rather lies in how the party's reference to nationalism has changed over time. We have thus explained the party's so-called 'normalisation' strategy through a theoretical framework of changing criteria of national belonging. 
In terms of our empirical contribution, we have undertaken extensive archival analysis to shed light on the ways in which the FN has reacted to acts of terrorism over time. To the authors' knowledge, there is no other empirical analysis of archival FN materials on terrorism, nor one comparing older archival materials with new materials across time on the topic. Our operationalization of the four categories of nationalism as the basis of coding FN positions is also innovative.

Our article opens several avenues for further research. While our findings apply only to the FN, they are in line with literature on the normalization of the far right more broadly. Therefore our analytical framework can yield results of comparative significance, as it means we can place the FN within the broader group of far-right parties that are increasing their levels of support by adopting similar narratives (Halikiopoulou et al., 2013). The pattern that we identify in this article is more likely to apply to Western European far-right parties, and especially those that are adopting civic nationalist narratives in their programmatic agendas such as the Alternative for Germany (AfD), the Austrian Freedom Party (FPÖ) and the Swiss People's Party (SVP). Future research could build on our framework by examining how such parties react to terrorism and whether their position on the issue has shifted over time. Indeed, there remains a lack of a general theory of how farright parties address the terrorism issue. It would also be worthwhile to examine whether there is a distinction between extreme-right and radical-right party positions on terrorism. As regards the FN specifically, the scope of our research has encompassed official discourse, focusing on the ways in which the party portrays itself to the broader public. Further research examining less formal means of communication directed at the party faithful could shed light on the broader picture of FN framing strategies and positions. Finally, our application of a four-pronged typology of nationalism offers a more nuanced approach than the ethnic-civic dichotomy and can facilitate future research in both theoretical perspectives and empirical analyses in nationalism studies more broadly.

\section{References}

Alduy, C. and Wahnich, S. 2015. Marine Le Pen prise aux mots: Décrytpage du nouveau discours frontiste. Paris: Seuil.

Arnautu, M.C. 2012. Communiqué de Presse de Marie-Christine Arnautu, Vice-présidente du Front National. 20 Apr. Available from :

http://www.frontnational.com/2012/04/communique-de-presse-de-marie-christine-arnautuvice-presidente-du-front-national/ (accessed 12 August 2016). 
Asari, E.M., Halikiopoulou, D. and Mock, S. 2008. 'British National Identity and the Dilemmas of Multiculturalism', Nationalism and Ethnic Politics, 14, 1: 1-28.

Bastow, S. 2018. The Front national under Marine Le Pen: a mainstream political party? French Politics, 16:19-37.

Bay, N. 2015. Lutte contre le terrorisme islamiste: les mesures dérisoires de l'UMPS. 23 January. Available from: http:/www.frontnational.com/2015/01/lutte-contre-le-terrorismeislamiste-les-mesures-derisoires-de-lumps/ (accessed 12 August 2016).

Betz, H.G. 2013. The New Front National: Still a Master Case? Recode Working Paper, Nov. 30.

Breuilly, J. 2005. 'Dating the nation: How old is an old nation?' in A. Ichijo and G. Uzelac (eds.), When is the nation? Towards an understanding of theories of nationalism. London: Routledge, 15-39.

Burscher, B., Spanje, J. van, and De Vreese, C. 2015. 'Owning the Issues of Crime and Immigration: The relation between immigration and crime news and anti-immigrant voting in 11 countries', Electoral Studies 38, 1: 59-69.

Crabtree, S. and Kluch, S. 2017. 'Terrorism, Migration Trouble many in Europe,' Gallup, 15 June. Available from: https://news.gallup.com/poll/212405/terrorism-migration-troubleeurope.aspx (accessed 15 Aug. 2018).

De Koster, W., Achterberg, P. and van der Waal, J. 2012. 'The New Right and the Welfare State: The Electoral Relevance of Welfare Chauvinism and Welfare Populism in the Netherlands', International Political Science Review 34,1: 3-20.

Descaves, P. 1996. '5 Vérites sur l'immigration', Français d'abord, 1 December: 10.

Dutheil de la Rochère, B. 2012. 'Le tueur islamiste aurait aussi bafoué le mariage dans l'impunité la plus totale'. 26 March. Available from:

http://www.frontnational.com/2012/03/le-tueur-islamiste-aurait-aussi-bafoue-le-mariagedans-limpunite-la-plus-totale/ (accessed 12 August 2016).

Eger, M.A. and S. Valdez. 2018. 'From radical right to neo-nationalist.' European Political Science. Online First, doi: 10.1057/s41304-018-0160-0 
Ennser, L. 2012. 'The homogeneity of West European party families: The radical right in comparative perspective', Party Politics 18: 151.

Ellinas, A. 2011. The media and the far right in Western Europe: Playing the Nationalist Card. Cambridge: Cambridge University Press.

European Commission. 2017. Standard Eurobarometer 87: Public Opinion in the European Union. Available from:

http://data.europa.eu/euodp/en/data/dataset/S2142_87_3_STD87_ENG/resource/0b3f5cc18e2d-437c-aa5b-2a03c980345b (accessed 15 August 2018).

Français d'abord. 1996. 'Multiplication des mosquées: Le FN riposte', 1 December: 8.

Français d'abord. 1995a. 'Gouvernement Chirac-Juppé: Premier bilan', 1 September: 4-5.

Français d'abord. 1995b. 'La Normandie n'est pas une terre d'Islam!' 15 October: 15.

Front National. 2002. Programme du Front National: Libérons la France! Available from: https://manifesto-project.wzb.eu//down/originals/31720_2002.pdf (accessed 23 Feb. 2019).

Front National. 2012. Mon Projet pour la France et les Français. Available from: https://manifesto-project.wzb.eu//down/originals/31720_2012.pdf (accessed 23 Feb. 2019).

Front National. 2015. Péril islamiste, Protégeons les Français. Available from: http://www.frontnational.com/2015/01/nouveau-tract-du-front-national-peril-islamisteprotegeons-les-francais/ (accessed 12 August 2016).

Front National. 2017. Engagements présidentiels Marine 2017. Available from: https://manifesto-project.wzb.eu//down/originals/2017-2/31720_2017.pdf (accessed 23 Feb. 2019).

Golder, M. 2003. 'Explaining Variation in the Success of Extreme Right Parties in Western Europe,' Comparative Political Studies 36, 4:432-66.

Gollnisch, B. 1996. Conséquences de l'immigration: La France éclatée. Français d'abord, December 15, 6 .

Gellner, E. 1998. Nations and Nationalism, London: Blackwell 
Hainmueller, J. and Hopkins, D.J. 2014. 'Public attitudes towards immigration', Annual Review of Political Science, 17: 225-249.

Hainsworth, P. 2008. The extreme right in Western Europe. Abingdon: Routledge.

Halikiopoulou, D., K. Nanou, and S. Vasilopoulou. 2012. 'The paradox of nationalism: The common denominator of radical right and radical left euroscepticism.' European Journal of Political Research 51(4): 504-539.

Halikiopoulou D, Mock S and Vasilopoulou, S. 2013. The civic zeitgeist: nationalism and liberal values in the European radical right. Nations and Nationalism 19(1):107-127.

Halikiopoulou D and Vlandas, T. 2016. Risks, costs and labour markets: explaining crossnational patterns of far right party success in European Parliament elections. Journal of Common Market Studies 54(3):636-655.

Hooghe, L. and Marks, G. 2017. 'Cleavage theory meets Europe's crises: Lipset, Rokkan, and the transnational cleavage', Journal of European Public Policy, DOI: 10.1080/13501763.2017.1310279.

Huntington, S.P. 1997. The Clash of Civilizations and the Remaking of World Order. New York :Touchstone

Hutchins, R.D. 2016. Nationalism and History Education: Curricula and Textbooks in the United States and France. New York: Routledge.

Immerzeel T, Lubbers $M$ and Coffé, H. 2015. Competing with the radical right: Distances between the European radical right and other parties on typical radical right issues. Party Politics 22(6):823-834.

Inglehart, R. and Norris, P. 2016. 'Trump, Brexit, and the Rise of Populism: Economic Have-Nots and Cultural Backlash', Harvard Kennedy School Faculty Research Working Paper Series [accessed on 26/01/17].

Ivaldi, G. 2015. Towards the median economic crisis voter? The new leftist economic agenda of the Front National in France. French Politics 13:346-369.

Ivarsflaten, E. 2008. What Unites Right-Wing Populists in Western Europe? ReExamining Grievance Mobilization Models in Seven Successful Cases. Comparative Political Studies 41(1):3-23. 
Kaufmann, E. 2002. Modern Formation, Ethnic Reformation: The Social Sources of the American Nation. Geopolitics 7(2):98-120.

Kohn, H. 1944. The Idea of Nationalism: A Study in its Origins and Background. New York: Macmillan.

Koopmans, R and Statham, P. 1999. Ethnic and civic conceptions of nationhood and the differential success of the extreme right in Germany and Italy. In: Giugni M, McAdam D and Tilly C (eds) How Social Movements Matter. Minneapolis, MN: University of Minnesota Press, pp.225-51.

Larsen, C.A. 2017. 'Revitalizing the 'civic' and 'ethnic' distinction. Perceptions of nationhood across two dimensions, 44 countries and two decades.' Nations and Nationalism. Online First, doi: 10.1111/nana.12345

La Lettre de Jean-Marie Le Pen. 1986 La Chronique politique de la quinzaine, October 15, 2.

Le Pen, J.M. 1986. Contre le terrorisme: Le vrai consensus. La Lettre de Jean-Marie Le Pen, October 1, 1.

Le Pen, J.M. 1995a. Editorial: Il n'a séduit qu'un seul été. Français d'abord, September 1, 2.

Le Pen, J.M. 1995b. Editorial: Terrorisme: A qui la faute? Français d'abord, October 15, 2 .

Le Pen, J.M. 1995c. Editorial: Demain la guerre civile? Français d'abord, November 1, 23.

Le Pen, J.M. 1996. Editorial: Vigie-Pilate. Français d'abord, December 1, 2.

Le Pen, M. 2012. Sur l'enterrement de Mohamed Merah en France. March 29. Available from: http://www.frontnational.com/2012/03/sur-lenterrement-de-mohamed-merah-enfrance/ (accessed 12 August 2016).

Le Pen, M. 2015a. Au moins un migrant parmi les terroristes : la France doit immédiatement arrêter l'entrée de migrants sur son territoire. November 16. Available from: http://www.frontnational.com/2015/11/au-moins-un-migrant-parmi-les-terroristes-lafrance-doit-immediatement-arreter-lentree-de-migrants-sur-son-territoire/ (accessed 12 August 2016). 
Le Pen, M. 2015b. How France will conquer the enemies of liberty. Time, November 17. Available from: http://time.com/4117119/paris-attacks-marine-le-pen/ (accessed 12 August 2016).

Lucassen, G. and M. Lubbers. 2012. "Who Fears What? Explaining Far-Right-Wing Preference in Europe by Distinguishing Perceived Cultural and Economic Ethnic Threats." Comparative Political Studies, 45(5): 547-574.

Maréchal-Le Pen, M. 2015. Question écrite de Marion Maréchal-Le Pen. January 28. Available from: http://www.frontnational.com/2015/01/question-ecrite-de-marionmarechal-le-pen-2/ (accessed 12 August 2016).

Mayda, A.M. 2006. "Who is against immigration? A cross-country investigation of individual attitudes toward immigrants." The Review of Economics and Statistics, 88:3, pp. $510-530$

Mayer, N. 2013. From Jean-Marie to Marine Le Pen: Electoral change on the far right. Parliamentary Affairs 66(1):160-178.

Mayer, N. 2015. The closing of the radical right gender gap in France? French Politics 13:391-414.

Mudde, C. 2007. Populist radical right parties in Europe. Cambridge; New York:

Cambridge University Press.

Mudde, C. 2010. 'The Populist Radical Right: A Pathological Normalcy', West European Politics, 33, 6: 1167-1186.

Philippot, F. 2015. Site web 'Stop-djihadisme': le gouvernement remet en cause la crédibilité de l'action publique. January 28. Available from: http://www.frontnational.com/2015/01/site-web-stop-djihadisme-le-gouvernement-remeten-cause-la-credibilite-de-laction-publique/ (accessed 12 August 2016).

Reeskens, T. and Hooghe, M. 2010. 'Beyond the civic-ethnic dichotomy: investigating the structure of citizenship concepts across thirty-three countries.' Nations and Nationalism 16(4): 579-597. 
Rydgren, J. 2008. 'Immigration sceptics, xenophobes or racists? Radical right-wing voting in six West European countries', European Journal of Political Research, 47: 737-765. doi:10.1111/j.1475-6765.2008.00784.x

Scott, J.W. 2007. The Politics of the Veil. Princeton, NJ: Princeton University Press.

Smith, A.D. 1991. National Identity. London: Penguin.

Stockemer, D. 2017. The Front National in France: Continuity and Change Under JeanMarie Le Pen and Marine Le Pen, Springer

Stockemer D. 2015. Structural Data on Immigration or Immigration Perceptions? What Accounts for the Electoral Success of the Radical Right in Europe? Journal of Common Market Studies 54(4):999- 1016.

Stockemer, D. and Amengay A. 2015. The voters of the FN under Jean-Marie Le Pen and Marine Le Pen: Continuity or change? French Politics 13:370-390. doi:10.1057/fp.2015.16

Taguieff, P.A. 1985. Le néo-racisme différentialiste. Sur l'ambiguïté d'une évidence commune et ses effets pervers. Langage et société 34:69-98. DOI: 10.3406/lsoc.1985.2039

Thomas, E.R. 2012. Immigration, Islam, and the Politics of Belonging in France: A Comparative Framework. Philadelphia: University of Pennsylvania Press.

Thooris, M. 2012. La bonne famille Merah. March 27. Available from: http://www.frontnational.com/2012/03/la-bonne-famille-merah/ (accessed 5 August 2016).

Van Spanje, J. 2010. Contagious parties: Anti-immigrant parties and their impact on other parties' immigration stances in contemporary Western Europe. Party Politics 16(5):563586.

Vasilopoulou, S. and Halikiopoulou, D. 2015. The Golden Dawn's nationalist Solution: Explaining the Rise of the Far Right in Greece. New York: Palgrave.

Vasilopoulos, P. 2018. Terrorist events, emotional reactions, and political participation: the 2015 Paris attacks, West European Politics, 41:1, 102-127, DOI: 10.1080/01402382.2017.1346901 
Vasilopoulos, P., Marcus, G. E. and Foucault, M. 2018. Emotional Responses to the Charlie Hebdo Attacks: Addressing the Authoritarianism Puzzle. Political Psychology, 39: 557-575. doi:10.1111/pops.12439

Wimmer, A. 1997. Explaining xenophobia and racism: a critical review of current research approaches. Ethnic and Racial Studies 20(1):17-41.

Zimmer, O. 2003. Boundary mechanisms and symbolic resources: Towards a processoriented approach to national identity. Nations and Nationalism 9(2):173-193.

\footnotetext{
${ }^{\mathrm{i}}$ Although the Front National changed their name to Rassemblement National in 2018, we refer to them using the name that was still in effect during the period studied here. ii This table draws on the Global Terrorism Database as well as a survey of Le Monde articles following each attack.

iii Any lag between the date of attacks and the publication of analysed materials is due either to publication schedules or an initial lack of information with regards to perpetrator. ${ }^{\text {iv }}$ Due to the cultural specificity of the term banlieue we employ the French term rather than the English translation.
} 